\title{
Different Perspectives \\ on Business Performance and Impact on Performance System Design ${ }^{\#}$
}

\author{
Zbyněk HALÍR $\check{R}^{*}$
}

\section{Introduction}

We can often hear that someone bought a new and high-performance car. Claims that among athletes competing in some sport the one with the best performance won is usual as well. Well performing (or efficient) employee can make entrusted tasks in a better way than his or her colleagues. A high-performance company succeeds in building up its competitive advantage and market position and makes happy its owners as well as other interested bodies.

In all the contexts above performance means an ability to perform well in particular situation, it means demonstrate a certain form of proficiency in some kind of acting. In this context proficiency can be understood as an ability to react to all incentives (originated especially in external but often also in internal environment) in a proper way.

In these days it is not important which professional discipline covers obtained information. More important is mutual interaction of financial accounting information, management accounting information, as well as business economics, microeconomics, management, logistics, marketing or HR management information. The thoughts of interdisciplinary approach were developed for example by Král (2010).

\footnotetext{
\# The article is processed as an output of a research project The Role of Management Accounting in Performance Measurements registered by the Internal Grant Agency (University of Economics, Prague) under the registration number F1/13/2012 and an output of the science institutional support project VŠEIP10040.

Ing. Zbyněk Halír - Ph.D. student; Management Accounting Department, Faculty of Finance and Accounting, University of Economics, Prague, W. Churchill Sq. 4, 13067 Prague, Czech Republic; <zbynek.halir@vse.cz>.
} 
Each of the professional disciplines mentioned above handles the issue of performance measurement with its own terminology, conceptions and models. The main contribution of this paper is analysis of a diverse body of knowledge of performance measurement issues from interdisciplinary point of view and subsequent effort to bring them into a coherent whole.

It is obvious that performance measurement is one of crucial tools that enable managers to manage and control companies. A question of performance measurement is observed by a variety of functional disciplines. If the matter of business performance is to be explored as a coherent whole then an interdisciplinary approach is needed.

The article is processed as an output of a research project The Role of Management Accounting in Performance Measurements registered by the Internal Grant Agency (University of Economics, Prague) under the registration number F1/13/2012.

The paper is also a follow-up to an earlier research project The Importance of Accounting Information in Financial Performance Measurements (also registered by the Internal Grant Agency of University of Economics in Prague under the registration number F1/21/2010), which was solved in 2010 and 2011. For more detailed information see Haliŕr (2010) and Halíř (2011b).

Previous project was oriented primarily to financial performance of an enterprise. The new one perceives business performance in a broader way (as defined by CIMA, 1982). Well the new project covers not only financial criteria, but also non-financial criteria and tools and chiefly its mutual integrity.

In this regard, the paper focuses mainly on the following objectives:

- To analyze a diverse body of knowledge of performance measurement issues from an interdisciplinary point of view and subsequently to bring them into a coherent whole;

- To analyze the role of management accounting in performance management system and to assess its importance, but also highlight areas where management accounting suffers from its limitations. 
Halír, Z.: Different Perspectives on Business Performance and Impact on Performance System Design.

\section{Historical background}

Principal object of performance measurement's attention - organised company operating in changing business environment - has been naturally sustainably changing over time. Subsequently performance measurement system as a whole, as well as its constituent elements (which means measures, methods, conceptions, ...) have to be changed as well.

Wagner (2011) segments historical development into three main phases. Each one of them has its own noticeable particularities:

1. Time period after the second World War -1950 s and 1960s;

2. 1970 s and $1980 \mathrm{~s}$;

3. The situation from 1990 s onwards.

\section{Time Period after the Second World War - 1950s and 1960s}

In the first phase Wagner (2011) identifies following significant characteristics:

- Relatively stable demand for mass production goods, stable prices of important inputs (raw materials, energy, ...);

- Relatively low level of foreign competition because of limited technology in logistics and communication;

- Low concentration of capital; direct management is usually used and power of decision is concentrated on the level of top management.

The result of these factors is the fact that business performance was seen especially in the operational and tactical horizon and future forecasts were based on the analogy of existing development. The key performance indicator at this developmental stage became profit or loss, respectively return on invested capital. Using the DuPont identity (used in the Du Pont Powder Company since the 20s of the 20th century) the majority of users of performance information were able to acquire sufficiently wide range of business information. 


\section{0s and 1980s}

In follow-up period (70s and 80s of the 20th century) there have been many changes in business environment. Significant characteristics of this phase are according to Wagner especially the following (Wagner, 2011):

- Growing level of concentration of capital; larger economic units with complex internal structure are created;

- Significant separation of ownership and management positions, and thus the mismatch between the objectives of owners and managers is growing;

- Development of target markets and of markets of inputs is not as stable as it had been before and continual search for competitive advantage over other companies is needed (for more detailed information see Porter, 1987).

The result of this development is that business performance is perceived rather in strategic time horizon. Looking to the future is founded mainly on assessing the impact of current company activities on its future development. Many new performance measures try to overcome the imperfections of profit or loss, which is considered a short-term oriented and therefore not suitable indicator. Among the most popular synthetic measures of performance (which is a measure that aims for expression of all the dimensions of current as well as future development of the company using one quantitative variable) which are trying to "remedy" belong EVA (Economic Value Added) and the emerging concepts of MVA (Market Value Added) and CFROI (Cash Flow Return on Investment) (for details about particular measures see e.g. Maříková and Mařík, 2005).

A natural consequence is the separation of the information needs of owners and managers of the company. Duality in conception of financial and managerial accounting is going broader. It is purposeful to divide all the involved subjects into two groups according to whether or not they have the opportunity to directly influence the activities, whose performance is under consideration. In the context of the abovementioned differentiation of decision-making tasks of individual subjects that are interested in the business, it is necessary to adequately distinguish the data within the accounting system. The natural result of these claims is the separation of accounting designed for external users (i.e. interest 
groups outside the enterprise) from accounting designed for internal use (accounting as an information support of management control).

The fact that each of these two systems reflects the needs of different group of users of accounting information results in their dual conception. This comes through especially by different recognition of assets and liabilities; different recognition of costs and revenues; different measurement (valuation) principles; different structure and detail of information displayed.

These issues have been examined and described within preceding research project. For more elaborated characterization see Halíŕ (2011a).

Another consequence is an understandable emphasis on the responsibility dimension of the performance. Thanks to information on the performance of the company its owner is able to determine whether managers are acting as expected. Following these findings the owner makes the decision to reward managers and to delegate their powers for the future periods. Performance measurement has then especially criterional and incentive function.

\section{From 1990s onwards}

Since the late 80 s of the 20th century more and more critical voices against the synthetic approaches to performance measurement which were on the forefront of interest in the previous two decades are growing. Wagner (2011) on the basis of the arguments of Johnson and Kaplan (1987) summarizes reasons for this criticism as following:

- measures that are based on a synthetic view of performance measurement capture business performance at such level of aggregation of information that makes it impossible to understand the causes leading to achieved performance;

- values of synthetic measures are only a reflection of earlier determined actions and do not reflect the ability of a company to create potential for future performance enhancement in competitive environment;

- synthetic measures assess the performance of a company as a whole and have no link to partial objectives and tasks, which are crucial for action of lower and middle management of a company; 
- All the synthetic measures are financial measures, but not all the effects can be expressed by means of financial information (especially in long-term time horizon).

Following the criticism series of proposals that say what characteristics should be met when designing the performance measurement system arise. Many authors - Globerson (1985), Maskell (1989), Blenkinsop and Davis (1991), Wisner and Fawcett (1991), Epstein and Manzoni (1997) - agree that the most important requirements are:

- Performance criteria must be derived from the company's objectives and related to company's strategy;

- Non-financial measures should be adopted;

- The measures should be designed so that they stimulate continuous improvement;

- Assure the compatibility of performance measures used in all functional areas;

- Criteria should be selected through discussions with the people involved, must be clear and provide fast feedback.

Perhaps the best known and the most sophisticated system of analytical performance measures is the concept of Balanced Scorecard (BSC), which integrates criteria and tools that were previously used mostly in isolation. It identifies relationships between four major prospects and links them with business vision and business strategy. A major contribution of this approach is a new understanding of the financial perspective. It is the attempt to create a more comprehensive measurement system of company's performance. Traditional measures considered the level of financial indicators as a determining factor in business performance. Thanks to the BSC concept much greater attention to the scales and measures, which are an important indicator of business performance in strategic time horizon, began to be given. The level of care for employees began to be taken into consideration as well as the way the company appears to its customers; it is also possible to express how important are the innovative activities, etc. Only as the impact of reaching the desired level of so-called value drivers, the objectives in terms of financial performance measures (so-called value results) can be met. 
Halír, Z.: Different Perspectives on Business Performance and Impact on Performance System Design.

BSC concept is based on the principle that a performance measurement system should provide managers with sufficient information to address the following questions (Kaplan and Norton, 1992):

- Financial perspective: How do we look to our stakeholders?

- Internal business perspective: What must we excel at?

- Customer perspective: How do our customers see us?

- Innovation and learning perspective: How can we continue to improve and create value?

Similar but probably less known is performance measurement framework proposed by Keegan et al. (1989) called "performance measurement matrix". It also seeks to integrate different dimensions of performance: internal dimension, external dimension, cost dimension and non-cost dimension. All the dimensions are relatively broad, so they are able to integrate for example "competitor perspective" better than the BSC concept.

Other authors proposed number of similar frameworks. One of them is for example Excellence Model introduced by European Foundation for Quality Management; another one is concept Six Sigma which was designed by Motorola.

\section{Further development}

Of course, the development of economic environment has not stopped at the end of the 20th century. The opposite is the truth. Last decade has brought many changes. The environment is more turbulent and unstable than it has been ever before.

In 2003 - 2007, the developing world experienced a massive economic boom. The boom was supported by many factors prevailing in global markets: exceptional financing, high commodity prices, etc.

These conditions have been replaced since September 2008 by the effects of financial turmoil that erupted in mid-2007 in the USA and which has later become probably the worst global financial crisis and recession since the Great Depression. Financial crisis has affected lending practices, customer demand and as a consequence economic activities of all companies. 
Another important change is connected with development of information technology, which means all technologies used to create, store, exchange and use information. The role of information technology as a supporting tool for business processes has increased considerably.

Advent and expansion of the Internet, communication software and database technologies enhanced global integration of business processes. Data input and analysis is much more flexible thanks to ERPS (Enterprise Resource Planning Systems), which is integrated information system comprising all information flows and based on a centralised database. These trends are also supported by development of standard models for electronic data representation - XML (eXtensible Mark-up Language) and XBRL (eXtensible Business Reporting Language) which were developed as a tool for automating of preparation, sharing and analysis of financial reports.

Further innovation is for example OLAP (OnLine Analytical Processing) database system, which is multidimensional analysis software tool that supports multidimensional understanding of performance.

\section{Business Performance Evolution}

All the tendencies described above resulted in new perspective on business performance. Until the 1960s "business performance" was perceived as financial performance of an assessed company.

The financial performance measures and benchmarks are in accordance with the usual traditional business objective of raising the value for the owner of the company.

The essence of business process is always the transformation of inputs to outputs. Inputs that were incurred in business process correspond to sacrifices that were mentioned above and outputs, which are gained thanks to the business process, then correspond to benefits that were mentioned above. In order to reach the desired level of financial performance, it is necessary that the value of total output exceeds the value of total input. The main motive of business is a general appreciation of inputs by gaining a higher output value.

Business performance is usually expressed simply by profit or loss. 


\section{Fig. 1: Transformation Process}

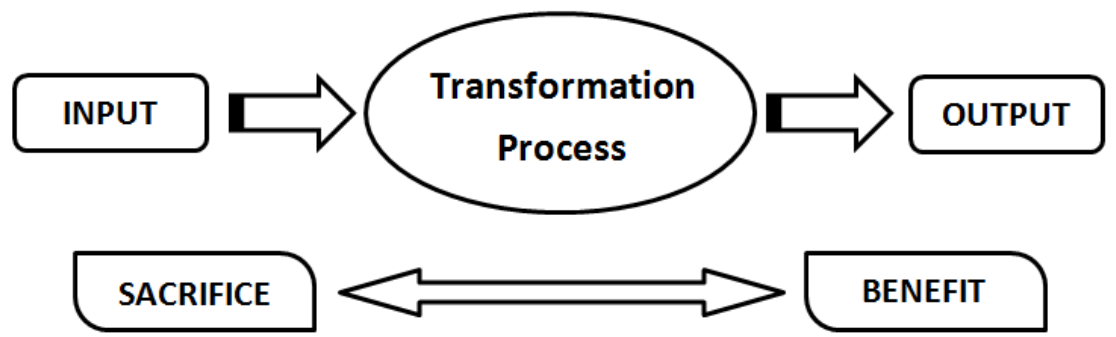

Source: Inspired by Fibírová, J., Šoljaková, L., Wagner, J. (2005)

From the relationship between costs incurred and economic benefits gained some important criteria for the rational development of the business process can be derived. The most important of these are measurements of economy, efficiency and effectiveness. Economy is rationality in the use of economic resources. The aim is to achieve desired outcomes at minimum cost. The effectiveness balances incurred costs against achieved economic benefits. This disparity is usually quantified by profit. Finally, efficiency is the ratio of effectiveness (i.e. profit) related to the total of economic resources employed.

In the 1970s economic environment changed relatively rapidly. More emphasise is put on strategic time horizon and profit or loss seemed to be insufficient for assessing business performance.

However, determination of targets and objectives is still derived from orientation primarily to maximizing value for business owners. This concept is based on shareholders theory. The performance is still understood primarily as increasing the value of capital invested by the owner of the company. This kind of performance can be suitably described by the financial measures, which results in understanding the business performance still only as financial performance.

In the course of time - especially during 1990 s - stakeholders theory has more and more forcefully come in useful. It assumes that the goal of an enterprise is to fulfil not only the company's owner's expectations, but also the expectations of other interested subjects in the company's surroundings. For some of these subjects many aspects are more important than the company's financial results. Performance is then to be 
understood more broadly. The assessment is no longer possible only through financial measures, indicators and benchmarks.

From the managerial point of view the fundamental problem is the fact that financial performance needs to be, of course, assessed by financial measures. The future potential of the performance has been increasingly emphasized. The main importance of information on company's performance is not in the retrospective assessment of the economic events, but in providing a basis for deciding on options for future development. The main task of measuring performance is to help to find answers to questions how our present and future decisions and actions contribute to the future benefit (Wagner, 2005).

The source of data for financial performance measures is an accounting system. However, accounting is tactically and operationally oriented tool and sometimes fails to reflect and satisfy the requirements for information support of strategic management. The financial performance measures and benchmarks are in accordance with the usual traditional business objective of raising the value for the owner of the company, but if we emphasize the potential of strategic business performance, many effects are proved in a way, that financial measures are not able to capture, or even in the opposite way, than the accounting shows them.

Only a comprehensive and complex performance reflects how the firm leads in a competitive environment and what its future growth prospect is like. Financial performance, which is based on traditional accounting data, is hierarchically subordinated item of a complex evaluation of company's performance. It is "only" a subset of such holistically understood performance.

Performance measurement is characterized as "the process of assessing the proficiency with which a reporting entity succeeds, by the economic acquisition of resources and their efficient and effective deployment, in achieving its objectives" (CIMA, 1982).

From such point of view it is beneficial to accept EFQM definition of performance "Performance is a level of reached results by individuals, groups, organizations and their processes" (EFQM, 1991). Such a performance is a characteristic, which assesses whether the business process helps to achieve business goals within a defined time period. If 
so, this characteristic should also measure the extent it occurs and assess what factors contribute to it.

While managing performance the managers strive to influence the economic subjects' development by a rational way - so that they would be able to fulfil the aims they have been founded for (Král, 2008).

Many analytical performance measures are based on this criticism. They are based on the idea that the performance of the company can be better described by a wide range of indicators that are directly tied to the level of future economic benefit, rather than by the general estimate of future benefit, that is expressed by one comprehensive (synthetic) measure. Systems of analytical performance measures are definitely much more suitable tools for the assessment and management of comprehensively understood and strategically oriented performance. That is, especially, for the following reasons:

- System contains natural criteria and measures, which have essential significance for assessing the financial performance in the long (strategic) run;

- Wide range of indicators allows their decomposition into subindicators, which are better understood by responsibility centres, which stand at a lower hierarchical level of organizational structure; it has a positive effect on their motivation, working moral and mutual communication and integration;

- Every company can create a system of measures and benchmarks, which will support its strategy and ensure its linkage with top objectives of the company;

- For all the above-mentioned reasons a comprehensive system of indicators is more effective management tool.

\section{Practical Implementation of Performance Measures}

On one hand theory and conception of performance measurement have developed significantly during recent decades, but on the other hand not all these ideas have been successfully implemented into practical life of companies. 
KPMG made a survey which found that:

- Most companies used targets and performance indicators based on internal financial standards. External comparisons and nonfinancial targets were not widely used. Internal information such as cost profiles, product profitability and past financial performance dominate the information set. External information is not widely used.

- Strategic planners of firms are less satisfied by than their accounting colleagues with the relevance, timeliness and completeness of the presented information.

- The primary objective of most of the companies is achievement of target earnings per share or market share. These objectives are measured by financial criteria in three quarters of organizations

These finding are supported by Neely and Mills (1993). They assert that especially in SMEs the cost of measurement is an issue of great concern to managers. Some responses go like "Measurement is a luxury success and failure are obvious."

The result is that even during these - post-crisis - days financial measures are often loudly criticised. They failed especially in strategic time horizon again. Sometimes they are not linked to factual substance of assessed activities at all. These issues have been discussed many times during last two decades (Kaplan and Norton, 1992; Kaplan and Norton, 1999, etc.).

\section{Modern Conception of Financial Performance}

As it was mentioned above requirements on management (and therefore necessarily also the measurement) of financial performance as a major factor in future growth potential of the business have evolved over time. The evolution, of course, must be reflected by appropriate development of management accounting, as the central instrument of management control. This development causes deepening and strengthening of the dual conception of financial and management accounting.

A number of developmental tendencies pervaded the text in previous chapters of the paper. At this point I consider it appropriate to summarize and organize these tendencies into a list. However, it does not pretend to 
be a complete listing, but rather strives to highlight the most important trends in measuring the financial performance and in the development of management accounting, which is an important tool for this measurement.

The performance of the company has been increasingly perceived as a potential for future success and growth, rather than as a simple glance in the past. The main task of measuring performance is to help to find answers to questions how our present and future decisions and actions contribute to the future benefit (see Wagner, 2005, p. 47). Business performance has been thus increasingly seen as a strategic parameter. In the long term, dynamics and success of business development and thus its performance depends mainly on the quality of its strategic management. Strong focus on the future requires the valuation of assets and liabilities, and consequently costs and revenues, based on expected future benefits or sacrifices (estimated present value of future benefits and sacrifices, estimates of market prices, etc.). Management accounting has adapted quite successfully for these requirements, while financial accounting in this regard remains - and must remain - more prudent and consequently more conservative. Valuation tied to future expectations is characterized by very high level of subjectivity, which is unacceptable in financial accounting, where is much more room for risk of abuse of information asymmetry between users and producers of reports informing about the performance.

An important amount of economic resources is spent during the innovation part of product lifecycle. The benefit of these resources, however, is approved by the revenue recognition much later than the expense had incurred. The matching of realized revenues and incurred costs should be based on the length of product lifecycle, rather than on traditional fixed (usually shorter) period. (For more details see Král et al., 2010.) Then it brings much higher information potential. This aspect primarily refers to the creation and use of intangible assets which are cornerstones of competitiveness of the companies today. These assets therefore belong among the most important items of assets (of balance sheet). Time period in which the company achieves benefits from the intangible assets is usually delayed in comparison with the period in which the economic resources were sacrificed and activities that have established the potential to generate future benefits were undertaken. At the moment of sacrificing these economic resources (which means creating of intangible assets) only estimating of future benefits is possible. In this regard financial accounting suffers for its prudence again. 
Just described time mismatch between the sacrifice of economic resources and getting the benefit from them is caused by increasing tendency to overcome the discontinuity of performance measurement. This limitation stems, inter alia, from performance measurement based on a fixed time period, for which the desired parameters are planned and budgeted. However, the final comparison may be made only when the evaluated process itself and all its direct consequences had been completed. Such aggregated information on the achieved performance can satisfy external users, whose mission is not to actively influence the business. However, such information is insufficient for company's management needs. Managers need to know not only information about the performance as whole, but especially detailed information about the factors that led to its achievement. Such information is, of course, obviously useful for external users too. Knowledge of the causes of performance achieved is an important aspect in further decision-making, because it allows making much better forecasts of future development. Managers of a company are responsible for its management, so they need information on performance as soon as possible. So that it is possible to influence and control the development of performance. It is too late to obtain such information when all processes have already taken place. In terms of time, therefore, demands for information of different groups of users are fundamentally different.

Another trend identified by Wagner (2005) and Král (2008), means the perception of performance as an internal source of the ability to achieve success in the external (market) environment. The objectives of the company and the chosen ways to achieve them, are usually formulated by managers of the company, however, the final performance recognized is always up to the external environment. This trend leads to the perception of business performance as the ability to satisfy the demands of all stakeholders and not only of the owners' ones. This idea is based on stakeholders theory and comes true in practice for example by application of analytical performance measures (an example was mentioned above it is Balanced Scorecard). In this regard, customer worth of paying special attention, because his or her decision to buy or not to buy the product of the company determines a competitive position of the company and the level of financial performance achieved. 


\section{Management Accounting Developmental Trends}

Changes in business environment are accompanied by development in the understanding, perceiving and measuring of performance. These changes must be, of course, reflected in the management accounting to be able to respond in a flexible way.

Many current trends stem from the effort to highlight the strategic perspective and its information support. In this context, however, the performance should be seen in broader concept than just as financial performance. In this chapter we will focus on developmental trends that are directly connected to shift in perception of the financial component of performance. These may include in particular (see Král, 2008):

- Management accounting as a financial (value) information system;

- Financial and non-financial management integrity;

- Change in time parameters of accounting information for operational and tactical management;

- Multidimensionality of management and its information support.

\section{Management accounting as a financial (value) information system}

Management accounting is still linked to traditional concept of accounting information; however, especially the pressure on the timeliness, richness and originality of the information for future decisionmaking makes it necessary to abandon the strict application of all elements of the accounting methodology. The information is often transformed beyond the double-entry accounting principles (such as product costing).

This trend is also documented by the above mentioned effort of management accounting to react to current issues of performance measurement. The effort results in increasing the scope of management accounting. Management accounting is defined rather by its user orientation (i.e. focus on the needs and demands of managers) than by the type of information (which would meet the characteristics of genuine accounting information) (Wagner, 2005). 


\section{Financial and non-financial management integrity}

There has been an increasingly strong pressure on linkage financial information with the natural (material) aspect of the business process. Complex performance measurement systems such as Balanced Scorecard, which links financial performance measures with a number of nonfinancial (natural) criteria, can be a suitable example.

The integrity also presents itself by tight linking of value quantities with natural aspect of the business process. It is necessary to see the specific operation or activity behind each piece of value information as well as the specific purpose of the expenditure of reasonable amount of economic resources.

\section{Change in time parameters of accounting information}

This change relates primarily to information for operational and tactical control. Pressure on the speedy presentation of accounting information is evident. Management accounting is abandoning the principles of reliability and relevance, because they necessarily imply a rigidity and delay of information. Management accounting focuses on providing a variety of reports reflecting the managerial needs with minimal time delay.

Due to the risks arising from information asymmetry the information with a high level of reliability has of course exceptional value in financial accounting. It is usually associated with reduction in timeliness of such information; however, it is an acceptable sacrifice for information credibility gained. It is not necessary to assume such strong conflict between interests of users and producers of management accounting information. It is therefore not necessary to separate the information that meets defined and harmonized requirements for the reliability from other information. It is possible to use not quite reliable and objective but timely information without a greater risk.

\section{Multidimensionality of management and its information support}

Manager, who manages business in today's complex and aggressive business environment, requires good information on the development of relevant variables in many aspects (points of view) simultaneously. These days it is standard practice to monitor information in the management line 
Halír, Z.: Different Perspectives on Business Performance and Impact on Performance System Design.

(aspect) of products, activities, sub-processes, processes, responsibility centres, customers, sales territories, distribution channels and possibly other useful aspects.

In my opinion, the financial accounting does not utilise the potential for assessment of financial performance, because it does not use the number of above mentioned aspects, in which information could be monitored. Financial accounting shows the reality only in a single aspect. While trying to find one - the most correct - point of view seems to be quite naive and by far not the best, financial accounting still sticks to this effort quite stubbornly. Evidence is the approach of IASB, which is reflected by the conceptual framework of IAS / IFRS. It says that the financial statements which meet the needs of investors also meet the most of needs of other users (see IASB, 2005).

Each group of users has its own information needs. If it is possible to strive for fulfilment of needs of all the groups, it is a shame to settle for a compromise approach described above. Demands of all stakeholders can never be fully satisfied in this case.

The generally accepted definitions of accounting features include the view of accounting as the purpose-oriented model of a company. Groups of many interested people, who strive for different goals, imply a lot of purposes, for which the accounting could and should serve. Monitoring and reporting of information in several aspects (dimensions) together (which is much easier these days thanks to the level of information technology development) ${ }^{1}$ would greatly increase the explanatory power of financial statements.

This approach obviously implies the need to differentiate between user groups. While using the internal information system of a company workers on different positions have different access rights to data store, it is also possible to differentiate between external users. For example, an investor who holds $40 \%$ of shares or bank that contributes significantly to the capital of the company will gain more detailed information in different structure than for example ordinary employees or even competitors.

\footnotetext{
${ }^{1}$ Let us mention the possibility of storing data in one central data store, in which each piece of information has a number of different attributes that reflect different views of different user groups. Differentiated demands for performance information are then only a matter of filtering data in the required structure and in the required database dimension due to database technologies and tools.
} 


\section{The role of management accounting in performance assessment}

Performance management can be considered as a primary goal of managers. Managing business performance means influencing the development of the company that was entrusted to manager's care in order to optimally fulfil the objectives which the company has been founded for. Such a responsible task can be performed only with a sufficiently wide range of adequate source information.

Thoughts about the role of management accounting in financial performance measurement, of course, cannot depend on whether management accounting itself (respectively its tools) can measure business performance, but rather on its integration with other systems and on its role in these relationships.

Performance management should necessarily integrate all the functions of a high-quality management control system, which means organizational function, planning function, controlling function, motivation function and last but not least, the information function, which penetrates all the above mentioned. Management accounting can be considered as an information tool of performance management system, so it can be characterized as an information-oriented performance management subsystem.

Now it is necessary to revert to question what is actually the scope and extent of management accounting. Former in the text the integration of information from financial and management accounting as well as from other professional disciplines (marketing, management, logistics or others) including information from the external environment of the company was commented. This complex integration of information leads to the fact that management accounting goes beyond its traditional scope (which means orientation exclusively to accounting and/or financial information).

I would go as far as to say that management accounting will not be able to manage the issue of performance management itself. An effort to find the chain of cause-and-effect logic that connects outcomes from the desired strategy with its drivers only through management accounting tools is not possible. It is necessary to realize that every dimension of performance is captured by some discipline. What are the measures of 
customer perspective of performance? Let's ask marketing, not management accounting! What are the measures of internal business perspective of performance? Let's ask logistics, information technologies or manufacturing management, not management accounting! How to measure performance of workers? Ask Human resource management, not management accounting! And what about the financial perspective of performance? Yes, management accounting is probably the right discipline to capture it.

What is the point? This complex and modern perception of performance measurement does not require broader scope of management accounting. First of all it requires its linkage with other fields related to the comprehensive management of the company. It can ensure the performance measurement methods in a wider meaning by comprehensive information support.

In the traditional approach to performance (for example in accordance with CIMA's definition, as defined above in the text) only financial (value) measures are included in scope of management accounting, while the measures of performance are often based as well on natural criteria. That is why the management accounting as an information support for the performance management system plays only a partial role.

The fact that the role of management accounting in performance management system is only partial, however, does not imply that management accounting, which has traditionally focused rather on operational and tactical level of management control, is not an appropriate management tool. The possibility of effective strategic performance management must necessarily be supported by effective operational and tactical procedures. In this regard, the role of management accounting is important. It is necessary to become aware of its proper linking to strategic objectives. 
Fig. 2: Hierarchy of Management Control

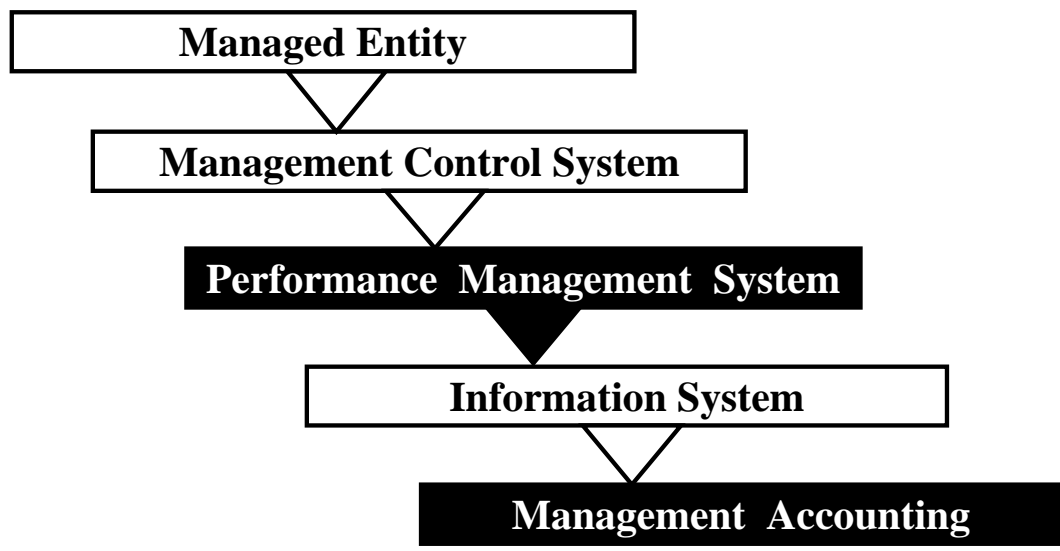

Source: Author's own elaboration

The mutual hierarchy makes clear that both management accounting and performance management system are influenced primarily by demands for efficient management control. However, this relationship should be also seen in reverse order. A prerequisite of effective management control is that both the performance management system, as well as management accounting system operate in conformity with each other and provide high-quality information to enable appropriate assessment of reality. That is the irreplaceable function of both these systems.

\section{Conclusion}

It is obvious that performance measurement is one of crucial tools that enable managers to manage and control companies. A question of performance measurement is observed by a variety of functional disciplines.

In these days it is not important which professional discipline covers obtained information. More important is mutual interaction of all the professional disciplines that handle the issue of performance measurement with its own terminology, conceptions and models. This paper emphasizes the necessity to bring a diverse body of knowledge of performance measurement issues into a coherent whole. 
Principal object of performance measurement's attention - organised company operating in changing business environment - has been naturally sustainably changing over time. Subsequently performance measurement system as a whole, as well as its constituent elements (which means measures, methods, conceptions, ...) had to be changed.

Until 1960s business performance was seen especially in the operational and tactical horizon and future forecasts were based on the analogy of existing development. The key performance indicator at this developmental stage became profit or loss, respectively return on invested capital.

In 1970s and 1980s business performance was perceived rather in strategic time horizon. Looking to the future is founded mainly on assessing the impact of current company activities on its future development. Many new performance measures try to overcome the imperfections of profit or loss, which is considered a short-term oriented and therefore not suitable indicator.

In this time period performance measurement is started to be significantly affected by user dimension. From the perspective of business management performance is a very broad-perceived characteristic, which reflects whether the company meets its objectives or not. From the perspective of external users performance is narrowed to assessing the financial performance and is limited by the accounting regulations.

In 1990s it was highlighted that performance measurement should capture business performance at such level of detail of information that makes it possible to understand the causes leading to achieved performance. All the synthetic measures from the past were financial measures, but not all the effects can be expressed by means of financial information (especially in long-term time horizon). New concepts such as Balanced Scorecard, Excellence Model, performance measurement matrix or Six Sigma were designed.

The information technologies have developed significantly since 2000 and their role as supporting tools for business processes has increased considerably. Especially advent and expansion of the Internet, communication software and database technologies enhanced global integration of business processes. 
As it was said above, the performance of the company has been increasingly perceived as a potential for future success and growth, rather than as a simple glance in the past. Business performance has been thus increasingly seen as a strategic parameter. Increasing tendency to overcome the discontinuity of performance measurement has been taking place. This effort stems from performance measurement based on a fixed time period, for which the desired parameters are planned and budgeted. However, the final comparison may be made only when the evaluated process itself and all its direct consequences had been completed. Performance has been increasingly perceived as an internal source of the ability to achieve success in the external (market) environment. The objectives of the company and the chosen ways to achieve them, are usually formulated by managers of the company, however, the final performance recognized is always up to the external environment. Management accounting has adapted quite successfully for these requirements, while financial accounting in this regard remains - and must remain - more prudent and consequently more conservative.

These changes must be, of course, reflected in the management accounting which is an important tool for measuring and managing performance to be able to respond in a flexible way. Developmental trends that are directly connected to shift in perception of the financial component of performance may include:

- Management accounting as a financial (value) information system;

- Financial and non-financial management integrity;

- Change in time parameters of accounting information for operational and tactical management;

- Multidimensionality of management and its information support.

Comprehensive performance management system (as being perceived by managers) requires besides financial criteria also a number of natural criteria. Performance management system goes far beyond the management accounting itself. An effort to find the chain of cause-andeffect logic that connects outcomes from the desired strategy with its drivers only through management accounting tools is not possible. It is necessary to realize that every dimension of performance is captured by some discipline.

This complex and modern perception of performance measurement does not require broader scope of management accounting. First of all it 
Halír, Z.: Different Perspectives on Business Performance and Impact on Performance System Design.

requires its linkage with other fields related to the comprehensive management of the company. It can ensure the performance measurement methods in a wider meaning by comprehensive information support.

Management accounting can be considered as an information tool of performance management system, so it can be characterized as an information-oriented performance management subsystem. The role of management accounting in performance management system is only partial (but still crucial).

\section{References}

[1] Blenkinsop, S. - Davis, L. (1991): The Road to Continuous Improvement. Insight, vol. 4, no. 3, pp. 23-26.

[2] CIMA (1982): Management Accounting - Official Terminology. London, Chartered Institute of Management Accountants, 1982.

[3] EFQM (1991): European Foundation for Quality Management. Brussels, EFQM 1999.

[4] Epstein, M. - Manzoni, J. F. (1997): The Balanced Scorecard and Tableau de Bord: Translating Strategy into Action. Management Accounting, 1997, vol. 79, no. 8, pp. 28-36.

[5] Fibírová, J. - Šoljaková, L. - Wagner, J. (2005): Nákladové účetnictví. Manažerské účetnictví I. (in English: Cost Accounting; Managerial Accounting I.). Praha, Oeconomica, 2005.

[6] Globerson, S. (1985): Issues in Developing a Performance Criteria System for an Organisation. International Journal of Production Research, 1985, vol. 23, no. 4, pp. 639-646.

[7] Halír, Z. (2010): The Role of Accounting Information in Financial Performance Measurements from External User's Viewpoint. European Financial and Accounting Journal, 2010, vol. 5, no. 2, pp. 25-52.

[8] Halír, Z. (2011a): High Quality Performance Measurement System as a Competitive Advantage. In Král, B. et al. (ed.): Performance Management: Where to Look for Competitive Advantage? Praha, Oeconomica, 2011, pp. 91-108.

[9] Halír, Z. (2011b): Accounting System and Financial Performance Measurements. European Financial and Accounting Journal, 2011, vol. 6 , no. 3, pp. 38-65. 
[10] IASB (2005): Mezinárodni standardy účetního výkaznictví. (in English: International Financial Reporting Standards). Praha, HZ, 2005

[11] Johnson, H. T. - Kaplan, R. S. (1987): Relevance Lost. The Rise and Fall of Management Accounting. Boston, Harvard Business School, 1987.

[12]Kaplan, R. S. - Norton, D. P. (1992): The Balanced Scorecard Measures That Drive Performance. Harvard Business Review, 1992, vol. 70, no. 1, pp. 71-79.

[13] Kaplan, R. S. - Norton, D. P. (1999): The Balanced Scorecard: Translating Strategy into Action, Boston, Harvard Business School, 1999.

[14] Keegan, D. P. - Eiler, R. G. - Jones, C. R. (1989): Are You Performance Measures Obsolete? Management Accounting, 1989, vol. 71, no. 6, pp. 45-50.

[15]Král, B. (2008): Performance Management and Managerial Accounting. In Král, B., et al. (ed.): Integrating Perspectives on Performance Management. Praha, Oeconomica, 2008, pp. 199-217.

[16] Král, B. (2010): Jak na interdisciplinaritu? (in English: How to deal with interdisciplinary approach?) In: Manažerská etika. (in English: Managerial Ethics.) Zlín: Univerzita Tomáše Bati, 2010.

[17] Král, B. et al. (2010): Manažerské účetnictví. (in English: Management Accounting) Praha, Management Press, 2010.

[18] Mařík, M. - Maříková, P. (2005): Moderni metody hodnocení výkonnosti a oceňování podniku. (in English: Progressive Methods for Assessment and Valuation of Firms). Praha, Ekopress, 2005.

[19] Maskell, B. (1989): Performance Measures of World Class Manufacturing. Management Accounting, 1989, vol. 67, no. 5, pp. 32-33.

[20]Neely, A. D. - Mills, J. F. (1993): Manufacturing in the UK-Report on a Survey of Performance Measurement and Strategy Issues in UK Manufacturing Companies. London, Manufacturing Engineering Group, 1993.

[21]Porter, M. (1987): From Competitive Advantage to Corporate Strategy. Harward Business Review, 1987, vol. 45, no. 2, pp. 43-59. 
Halír, Z.: Different Perspectives on Business Performance and Impact on Performance System Design.

[22] Wisner, J. D. - Fawcett, S. E., (1991): Link Firm Strategy to Operating Decisions through Performance Measurement. Production and Inventory Management Journal, 1991, vol. 32, no. 3, pp. 5-11.

[23] Wagner, J. (2005): Potenciál účetních informací pro měrení finanční výkonnosti. (in English: Accounting Information Potential for Performance Measurement). Praha, University of Economics, 2005, Doctoral Thesis.

[24] Wagner, J. (2011): Měření výkonnosti-vývojové tendence 2. poloviny 20. století. (In English: Performance Measurement - Developing Tendencies of the Second Half of the 20th Century). Politická ekonomie, 2011, vol. 59, no. 6, pp. 775-793. 


\title{
Different Perspectives on Business Performance and Impact on Performance System Design
}

\author{
Zbyněk HALÍR̆
}

\begin{abstract}
Currently, increasing emphasis is placed on performance measurement and management. The paper is concerned with the connection between the performance of an enterprise in general and financial performance. This connection has been naturally sustainably changing over time. Question of performance measurement is observed by a variety of functional disciplines. The paper emphasizes the necessity to bring a diverse body of knowledge of performance measurement issues into a coherent whole. In subsequent part it deals with summarizing the most important developmental tendencies of financial performance measurement and management accounting and with analysing of the relation of performance management and management accounting.
\end{abstract}

Key words: Performance Measurement, Management Accounting, Business Performance, Developmental Trends

JEL classification: M41. 